\title{
CONTROL OF AMMONIA EMISSIONS IN NATURALLY VENTILATED DAIRY CATTLE FACILITIES IN PORTUGAL
}

\section{JOSÉ PEREIRA ${ }^{1}$, HENRIQUE TRINDADE ${ }^{2}$}

\begin{abstract}
We conducted a study of the processes associated to $\mathrm{NH}_{3}$ emission in naturally ventilated dairy cattle facilities, having described factors that regulate $\mathrm{NH}_{3}$ emission, as well as methodologies for measuring these emissions at these facilities. Appropriate techniques to mitigate $\mathrm{NH}_{3}$ emission in facilities located in regions with warm climates were also identified. The most effective mitigation techniques with simple implementation include strategies associated to: (i) installation design and flooring, which lead to reduced emissions, (ii) excreta pre-excretion, namely the use of diets with optimized crude protein content and increased milk production at farm level; and (iii) excreta post-excretion, particularly by changing the conditions of environmental monitoring within the premises, practice introduction or additive application in the management of excreta deposited on floors.
\end{abstract}

KEYWORDS: facilities, gases, methods, floors, mitigation techniques.

\section{CONTROLE DAS EMISSÕES DE AMONÍACO EM INSTALAÇÕES NATURALMENTE VENTILADAS PARA BOVINOS DE LEITE EM PORTUGAL}

RESUMO: Efetuou-se um estudo sobre os processos associados à emissão de $\mathrm{NH}_{3}$ em instalações naturalmente ventiladas para bovinos de leite, tendo sido descritos os fatores que regulam a emissão de $\mathrm{NH}_{3}$, assim como metodologias de medição destas emissões nestas instalações. Foram, também, identificadas técnicas adequadas de mitigação da emissão de $\mathrm{NH}_{3}$ em instalações localizadas em regiões com climas quentes. As técnicas de mitigação mais eficazes e de implementação simples incluem estratégias associadas: (i) ao projeto das instalações e pavimentos que conduzam a emissões reduzidas; (ii) à pré-excreção das dejeções, nomeadamente a utilização de dietas com teor otimizado de proteína bruta e o aumento da produção de leite ao nível da exploração; e (iii) à pósexcreção das dejeções, sobretudo pela alteração das condições de controlo ambiental no interior das instalações, introdução de práticas ou aplicação de aditivos no manejo das dejeções depositadas sobre os pavimentos.

PALAVRAS-CHAVE: edifícios, gases, métodos, pavimentos, técnicas de mitigação.

\section{INTRODUCTION}

Livestock production is facing increased pressures from society to comply with environmental legislation, so that production systems are exploited in a sustainable and environmentally friendly manner. As a result of Directive 96/61/EC of the European Union (EU) for integrated prevention and control of pollution, each Member State shall prepare and implement the best available techniques for environment protection. More recently, Directive 2001/81/EC on maximum National emission limits, estates that in 2010 each EU Member State should limit gaseous pollutant emissions that lead to acidification and eutrophication, such as ammonia $\left(\mathrm{NH}_{3}\right)$ and nitric oxide (NO), by $10 \%$. When the Gothenburg Protocol is fully implemented in the EU, $\mathrm{NH}_{3}$ emissions must

\footnotetext{
${ }^{1}$ Sanitary Engineer, Doctor, Centre for the Research and Technology of Agro-Environmental and Biological Sciences, CITAB, University of Trás-os-Montes and Alto Douro, UTAD, Quinta de Prados, 5000-801, Vila Real, Portugal; and Polytechnic Institute of Viseu, IPV, Agricultural Polytechnic School of Viseu, ESAV, Quinta da Alagoa, 3500-606, Viseu, Portugal, Phone: (+351) 232446600, jlpereira@esav.ipv.pt.

2 Agricultural Engineer, Doctor, Centre for the Research and Technology of Agro-Environmental and Biological Sciences, CITAB, University of Trás-os-Montes and Alto Douro, UTAD, Quinta de Prados, 5000-801, Vila Real, Portugal, htrindad@utad.pt. 
be reduced by 17\% compared to 1990 levels (MELSE et al., 2009). Acidifying pollutant depositions such as $\mathrm{NH}_{3}$ has a number of negative effects on ecosystems and degradation of materials and existing facilities. Also, $\mathrm{NH}_{3}$ volatilization can cause direct damage to plants/crops grown in the vicinity of livestock farms (dry deposition) and also the formation of acid rain (wet deposition) that lead to changes in ecosystems. Furthermore, $\mathrm{NH}_{3}$ is also a precursor of nitrous oxide $\left(\mathrm{N}_{2} \mathrm{O}\right)$, which in turn contributes to increase greenhouse effect and ozone layer depletion.

The $\mathrm{NH}_{3}$ emissions occur at all waste management stages (facilities, storage and soil application), which represent about $75 \%$ of total $\mathrm{NH}_{3}$ emissions in Europe (PEREIRA, 2010). Livestock facilities have been identified as the largest source of air pollution by agriculture due to contaminant gas emissions (FURTADO et al., 2012). The livestock facility ventilation need leads to gases and polluted air emission in the vicinity of facilities (FURTADO et al., 2010; TOLON et al., 2010), and therefore may present a risk for animal and human health (FURTADO et al., 2012). $\mathrm{NH}_{3}$ emission has as origin the $\mathrm{N}$ excreted by animals in urea form and other $\mathrm{N}$ organic forms within the premises of facilities or outdoors or in adjacent areas, such as parks, feeding areas, storage tanks, animal traffic areas and waiting areas, for example, milking parlors. The bovine excrete excess of $\mathrm{N}$ from the diet in urea form in urine and undigested proteins in feces. This urine urea and existing undigested proteins in feces representing about $70 \%$ of total $\mathrm{N}$ ingested by cattle, with the remaining 30\% excreted in the milk and/or retained in live weight gain, however these excreted levels can vary considerably. The nitrogen compounds such as urea, ammonium $\mathrm{N}(\mathrm{NH} 4+), \mathrm{NH}_{3}$ and undigested proteins are potential sources for $\mathrm{NH}_{3}$ volatilization (HRISTOV et al., 2011).

With the Kyoto Protocol, there was an urgent need to quantify and established practices to reduce gas emissions from livestock facilities emerged, leading to the scientific work development especially in Northern European countries, verifying a very limited number of studies for warmer regions, as with Portugal. The aim of this study was to identify proper techniques to quantify and mitigate $\mathrm{NH}_{3}$ emissions in naturally ventilated facilities of dairy cattle for Portugal conditions.

\section{SUBJECT DESCRIPTION}

\section{$\mathrm{NH}_{3}$ volatilization}

Total ammonia $\mathrm{N}\left(\mathrm{NH} 4++\mathrm{NH}_{3}\right)$ is the source of $\mathrm{NH}_{3}$ emission from animal production systems which, in turn, in cattle effluent originated mainly from urea hydrolysis present in urine (PEREIRA et al., 2011; 2012). An excess of metabolizable protein compared to the needed amount to achieve required levels of production will reduce the use efficiency by ruminant, resulting in $\mathrm{N}$ lost in urea form via urine (PEREIRA et al., 2010). For the $\mathrm{N}$ excreted in urine, the larger nitrogenous component is urea which is 50 to $90 \%$ of $\mathrm{N}$ present compounds (PEREIRA et al., 2012). The potential $\mathrm{NH}_{3}$ volatilization emanating from existing nitrogen compounds in excreta decreases in the following order: urea $>$ alantoin $>$ uric acid $>$ creatinine $>$ creatine $\approx$ hippuric acid $>$ xanthine $>$ hypoxanthine. Cattle feces contain low levels of $\mathrm{N}$ forms which are rapidly decomposable because only a small percentage of $\mathrm{N}$ in fresh manure is in the forms of $\mathrm{NH} 4+$ or urea, suggesting that the potential for $\mathrm{NH}_{3}$ volatilization in fresh manure is relatively low (HRISTOV et al., 2011).

Urea is a diamide which, in a first stage, is converted by the enzyme urease into ammonium carbonate $\left(\left(\mathrm{NH}_{4}\right)_{2} \mathrm{CO}_{3}\right)$ [eq. (1)] and, in a second stage, undergoes dissociation into $\mathrm{NH} 4+, \mathrm{CO}_{2}$ (gaseous) and water [eq. (2)]. The hydrolysis reaction consumes $\mathrm{H}^{+}$and $\mathrm{pH}$ increase occurs, thus leading to imbalance of $\mathrm{NH} 4+/ \mathrm{NH}_{3}$ balance, increasing the $\mathrm{NH}_{3}$ volatilization [eq. (3)]. The urea hydrolysis follows first order kinetics Michaelis-Menten for conversion in basic enzyme processes (PEREIRA, 2010).

$$
\begin{aligned}
& \mathrm{CO}\left(\mathrm{NH}_{2}\right)_{2}+2 \mathrm{H}_{2} \mathrm{O} \Rightarrow\left(\mathrm{NH}_{4}\right)_{2} \mathrm{CO}_{3} \\
& \left(\mathrm{NH}_{4}\right)_{2} \mathrm{CO}_{3}+2 \mathrm{H}^{+} \Rightarrow 2 \mathrm{NH}_{4}^{+}+\mathrm{CO}_{2} \uparrow+\mathrm{H}_{2} \mathrm{O}
\end{aligned}
$$




$$
\mathrm{NH}_{4}^{+}+\mathrm{OH}^{-} \Leftrightarrow \mathrm{NH}_{3} \uparrow+\mathrm{H}_{2} \mathrm{O}
$$

Feces excreted by animals contain bacteria which produce urease, whereby it is present on the floors of premises and in soils, as well as in the soil of fattening parks and outdoor parks (PEREIRA et al., 2011). In cattle facilities the existence of urease is positively correlated to the surface roughness of the floors, with activity of $1.4 \mathrm{~g} \mathrm{NH} 4+-\mathrm{N} \mathrm{m}^{-2} \mathrm{~h}^{-1}$ (PEREIRA et al., 2011). Hydrolysis of urea is affected by the $\mathrm{pH}$ value, and the optimal value of this parameter suitable for urease activity is between 6 and 9 (SOMMER et al., 2006). The urease activity on floors is very persistent, and only a thorough cleaning (i.e., with strong acids) can reduce its presence (OGINK \& KROODSMA, 1996). Also, urease activity is affected by temperature, being low at temperatures below $5{ }^{\circ} \mathrm{C}$ and above $60^{\circ} \mathrm{C}$, increasing exponentially between 5 and $40{ }^{\circ} \mathrm{C}$ (RONG et al., 2009; PEREIRA et al., 2012)

\section{NH3 transport model outward from facilities}

The physical process of transporting $\mathrm{NH}_{3}$ from emission sources (i.e., facilities, outdoor parks, waiting and exercise areas, and storage tanks) can be described using an approach to transport resistance. The calculation of $\mathrm{NH}_{3}$ transport resistance varies between different conditions of climate control of facilities, as well as in different design situations, storage tanks and exterior fattening parks (such as geometry and position of the inlet and outlet air). The physical and chemical processes leading to $\mathrm{NH}_{3}$ emission from dirty areas with excreta (such as floors, ditch walls for excreta removal, storage tanks, and effluent superficial area which is stored below floors inside premises) may differ; in that for its estimate, it is necessary to determine emissions for each surface (Figure 1). For this purpose, the calculations must take into account the time during which a surface may be an emission source, and it may vary from a few hours at locations where urine was deposited, to continuous emissions. From effluent surface, below the floors, resistances associated with $\mathrm{NH}_{3}$ transport may include the following steps: (i) transport from effluent surface to the floor; (ii) through the floor (iii) from the floor to the facility's air outlet and (iv) through air outlet openings to atmospheric air (SOMMER et al., 2006). The $\mathrm{NH}_{3}$ emission from all emission sources can be calculated by eq. (4).

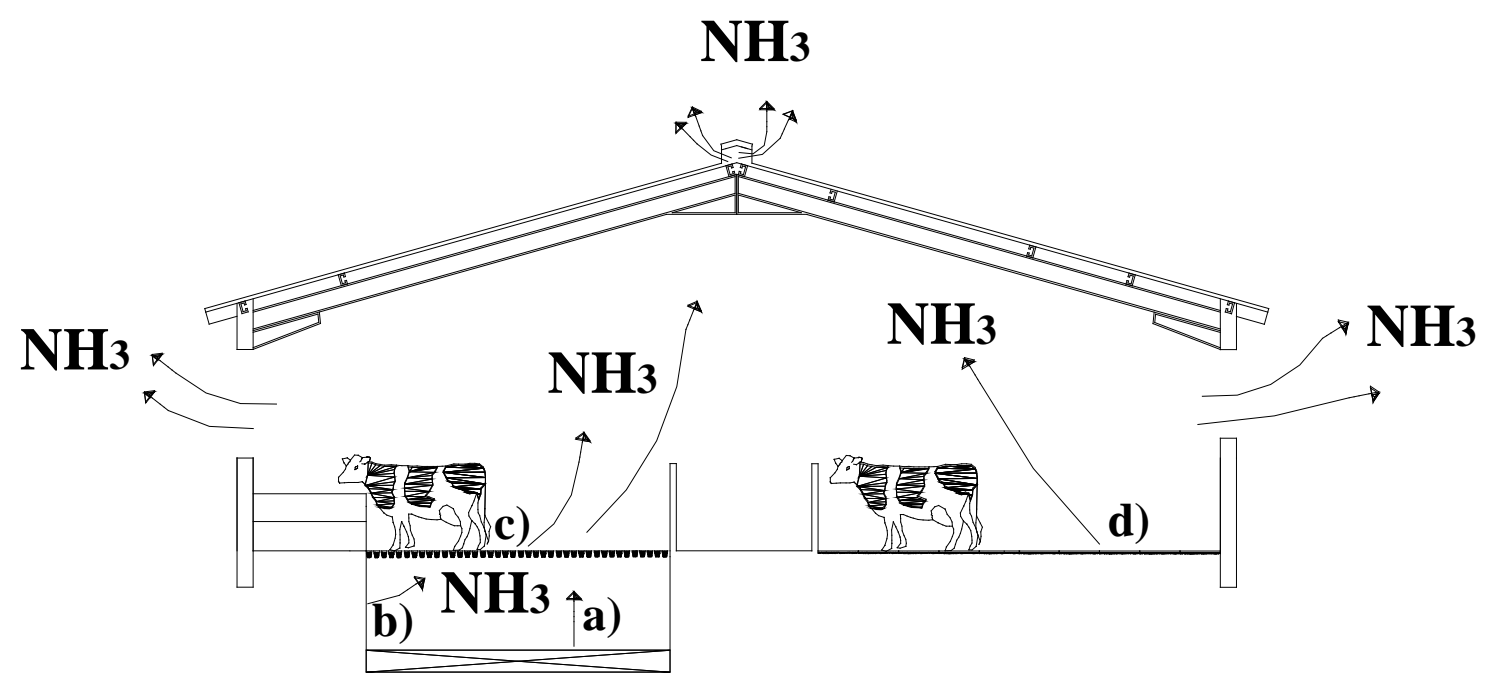

FIGURE 1. Conceptual model of $\mathrm{NH}_{3}$ transport processes in dairy cattle facilities (adapted from SOMMER et al., 2006).

In which the total $\mathrm{NH}_{3}$ flux from the facility is given by emissions from each source: (a) effluent surface in the removal or storage channel; (b) channel walls dirty with effluent; (c) slatted floor over the channel, and (d) solid floor with excreta deposited on the surface. 


$$
\mathrm{F}_{\mathrm{NH}_{3}}=\frac{1}{\mathrm{r}_{1}+\mathrm{r}_{2}+\cdots+\mathrm{r}_{\mathrm{n}}} \mathrm{A}\left(\mathrm{NH}_{3, \mathrm{~g}}-\mathrm{NH}_{3, \mathrm{~A}}\right)
$$

where,

$\mathrm{F}_{\mathrm{NH} 3}$ - total $\mathrm{NH}_{3}$ flow;

A - $\mathrm{NH}_{3}$ emission source surface area;

$\mathrm{r}_{1}-\mathrm{r}_{\mathrm{n}}$ - resistances to $\mathrm{NH}_{3}$ transport between the emitting surface and free atmosphere, which are affected by ventilation (or wind) and contact surface parameters (roughness);

$\mathrm{NH}_{3, \mathrm{~g}}-\mathrm{NH}_{3}$ atmospheric concentration in the air layer immediately above surface, and

$\mathrm{NH}_{3}$, A $-\mathrm{NH}_{3}$ concentration in exterior environment atmosphere. However, it is common to ignore $\mathrm{NH}_{3, \mathrm{~A}}$ as its concentration is low compared to $\mathrm{NH}_{3, \mathrm{~g}}$.

\section{$\mathrm{NH}_{3}$ emission measurement in naturally ventilated facilities}

In recent years a set of techniques for $\mathrm{NH}_{3}$ emission measurement in livestock facilities have been developed and validated in field conditions, even for facility case where existing $\mathrm{NH}_{3}$ concentrations are low (DORE et al, 2004; NI \& HEBER, 2008; SAMER et al., 2011, 2012). Recent studies have suggested that to quantify facility emission, ventilation flow rate and air gas concentrations emitted through the air outlet openings must be known [eq. (5)], and a key aspect to the emission rate determination is to calculate the air exchange rate in the facility (NGWABIE et al., 2009; SAMER et al., 2011). In this perspective, the $\mathrm{NH}_{3}$ emission determination from facilities with forced ventilation is considered a standard procedure; however, in natural ventilation facilities the determination is more complex, since in forced ventilation the flow rate ventilation determination is simpler than the natural one (e.g. using anemometers) as air flow intake or exhaust are controlled by fans.

$$
\mathrm{E}_{\mathrm{NH}_{3}}=\frac{\mathrm{CV}\left(\mathrm{C}_{\text {in }}-\mathrm{C}_{\text {out }}\right)}{\mathrm{n}}
$$

where,

$\mathrm{E}_{\mathrm{NH} 3}-\mathrm{NH}_{3}$ emission (animal mg h ${ }^{-1}$ );

$\mathrm{CV}$ - ventilation flow rate $\left(\mathrm{m}^{3} \mathrm{~h}^{-1}\right)$ obtained for a $24 \mathrm{~h}$ period;

$\mathrm{C}_{\text {in }}$ and $\mathrm{C}_{\text {out }}-\mathrm{NH}_{3}$ concentrations $\left(\mathrm{mg} \mathrm{m}^{-3}\right)$ inside and outside the facility, respectively, and

$\mathrm{n}$ - total number of animals housed in the building.

For example, the protocol currently used in Netherlands for $\mathrm{NH}_{3}$ emission measurement from livestock facilities specifies that they must be performed considering the airflow coming out of the facilities (ventilation flow rate or air exchange rate) and average $\mathrm{NH}_{3}$ atmosphere concentration with the exiting air in the facilities, the $\mathrm{NH}_{3}$ emission being calculated as the product of ventilation flow rate and average $\mathrm{NH}_{3}$ concentration (MOSQUERA et al., 2005). In the case of livestock facilities with forced ventilation, where air emitted is extracted by the ventilation system, the protocol currently used in Netherlands specifies the use of $\mathrm{N}$ oxide $\left(\mathrm{NO}_{\mathrm{x}}\right)$ analyzer coupled to a thermal $\mathrm{NH}_{3}$ converter, or a photo-acoustic gas analyzer with infrared to measure the $\mathrm{NH}_{3}$ concentrations and an airspeed sensor, placed in the ventilation system, for measuring ventilation flow rate.

For facilities with natural ventilation, which is the case for most of the existing facilities for dairy cattle in Portugal, the air renewal in this ventilation system is controlled by the processes of thermal lift and wind speed, which in most situations work together. These facilities generally have large air inlets and outlets, which sometimes may be part or even the total area of transverse and/ or longitudinal building faces. In such cases air renewal depends on wind speed and direction, and a wide range of ventilation patterns can be observed. There is also a large uncertainty regarding to the building openings that serve as air inlets and outlets, as they can vary from day to day and even during the day (or within hours) (PEREIRA et al., 2010). 
Several studies have shown that for the $\mathrm{NH}_{3}$ emission measurement from naturally ventilated livestock facilities we can use methods or techniques that are based on the ventilation flow rate estimate and $\mathrm{NH}_{3}$ concentration emitted in the air, thus obtaining the emission (DORE et al., 2004; SAMER et al., 2011, 2012 ), or in methods that allow to estimate or quantify the $\mathrm{NH}_{3}$ flow based on micrometeorological methods, including various configurations of flow sampling passive devices (commonly known as Ferm tubes) have shown robust results (DORE et al., 2004; PEREIRA et al., 2010).

\section{Techniques based on the ventilation flow rate estimate}

Several methods for $\mathrm{NH}_{3}$ emission measurement based on ventilation flow rate have been used and compared, among which those that have shown more effective results and have been accepted as measurement techniques are: (i) tracer gas [eq. (6)], where there is gas application, used as tracers (i.e. krypton $-85\left(\mathrm{Kr}^{85}\right)$, sulfur hexafluoride $\left(\mathrm{SF}_{6}\right)$, sulfur pentafluoride trifluoromethyl $\left(\mathrm{SF}_{5} \mathrm{CF}_{3}\right)$ ); and (ii) mass balance $\left(\mathrm{CO}_{2}\right)$ [eq. (7)] and energy (heat), in which it is assumed that the heat and $\mathrm{CO}_{2}$ produced by the animals in the facility can be determined from previously validated models, and these factors are used to estimate $\mathrm{NH}_{3}$ emissions by comparison (DORE et al., 2004; TEYE \& HAUTALA, 2008; NGWABIE et al., 2009; SAMER et al., 2011, 2012; SCHRADE et al., 2012). The use of tracer gas has been identified as a reliable method for estimating gaseous emissions from naturally ventilated livestock facilities, but the $\mathrm{CO}_{2}$ balance is also commonly used (SAMER et al., 2011, 2012).

$$
\mathrm{CV}_{\mathrm{T}}=\frac{\left(\operatorname{In} \mathrm{C}_{0}-\operatorname{In} \mathrm{C}_{1}\right)}{\mathrm{T}} \mathrm{V}
$$

where,

$\mathrm{CV}_{\mathrm{T}}$ - ventilation flow rate $\left(\mathrm{m}^{3} \mathrm{~h}^{-1}\right)$ estimated using tracer gas (in decay);

$\mathrm{c}_{0}$ - concentration of tracer gas in time 0 (maximum) in ppm;

$\mathrm{c}_{1}$ - concentration of tracer gas in time 1 (minimum and close to detection limit) in ppm;

$\mathrm{T}$ - time measurement between $\mathrm{c}_{0}$ and $\mathrm{c}_{1}$ values obtained (in hours), and

$\mathrm{V}$ - building volume $\left(\mathrm{m}^{3}\right)$.

$$
\mathrm{CV}_{\mathrm{CO}_{2}}=\frac{\mathrm{n} \mathrm{\textrm {P } _ { \mathrm { CO } _ { 2 } }}}{\rho_{\mathrm{CO}_{2}}\left(\mathrm{C}_{\text {in }}-\mathrm{C}_{\text {out }}\right) 10^{-6}}
$$

where,

$\mathrm{CV}_{\mathrm{CO} 2}$ - ventilation flow rate $\left(\mathrm{m}^{3} \mathrm{~h}^{-1}\right)$ estimated based on $\mathrm{CO}_{2}$ balance;

$\mathrm{n}$ - total number of animals housed in the facility;

$\mathrm{P}_{\mathrm{CO} 2}-\mathrm{CO}_{2}$ individual production by animals $\left(\mathrm{g} \mathrm{h}^{-1}\right)$;

$\mathrm{C}_{\text {in }}$ and $\mathrm{C}_{\text {out }}-\mathrm{CO}_{2}$ concentrations $\left(\mathrm{g} \mathrm{m}^{-3}\right)$ inside and outside the building, respectively, and

$\rho_{\mathrm{CO} 2}=\mathrm{CO}_{2}$ density.

\section{$\mathrm{NH}_{3}$ flow quantification}

The $\mathrm{NH}_{3}$ emission quantifications also been made by using various configurations of sampling flow passive devices, which are based on measuring $\mathrm{NH}_{3}$ flow in emission sources, for example in livestock facilities with natural ventilation (DORE et al., 2004; PEREIRA et al., 2010) and parks and other outdoor areas (MISSELBROOK et al., 2006; NI \& HEBER, 2008).

The Ferm tubes consist in the use of tube pairs arranged in series or according to the same axis, in which an air flow passes, controlled by a hole in the between the tube pair connection. In each tube a filter paper impregnated with $\mathrm{NH}_{3}$ adsorbent acid (usually sulfuric acid) is previously introduced, allowing it to capture the $\mathrm{NH}_{3}$ flow from the air in proportion to exposure time (DORE et al., 2004). The arrangement of a Ferm tube set properly distributed wraparound the emission source, which are the air inlet and outlet of a building, allows obtaining the fluid flow that is given 
by numerical integration of $\mathrm{NH}_{3}$ liquid flow values obtained in each sampling area (PEREIRA et al., 2010). The total emission from each building is calculated as the emission sum from all areas of monitored openings [eq. (8)].

$$
\sum_{n=0}^{n=n}\left[\left(\frac{A_{n}}{X_{s} a}\right)\left(\frac{M_{n}}{t_{n}}\right)\right]
$$

In which $A_{n}$ (in $\mathrm{m}^{2}$ ) is the air gap area monitored by the device $n$, $a\left(\right.$ in $\mathrm{m}^{2}$ ) is the hole area on the device and $X_{s}$ is the device constant. The reason $A_{n} /\left(X_{s} \times a\right)$ is the correction factor between the air gap area and the hole area of each device. $M_{n}$ (in $\mu \mathrm{g}$ ) is the $\mathrm{NH}_{3}$ net value retained on the device (i.e. the $\mathrm{NH}_{3}$ amount collected in the leaving air flow rate minus the air flow rate entering through the building ventilation); the $\mathrm{NH}_{3}$ flow to an air opening is given by dividing $M_{n}$ by the exposure time $t_{n}$ (in seconds).

\section{Techniques to mitigate $\mathrm{NH}_{3}$ emission}

$\mathrm{NH}_{3}$ emission from cattle facilities depends on several key factors including temperature, air speed, ventilation flow rate, floor type, diet and its composition, and excreta removal system (SOMMER et al., 2006; PEREIRA et al., 2010; SCHRADE et al., 2012). Consequently, the emission originated in cattle facilities, used in livestock production systems of various European countries will be different, and higher values were observed in Portugal compared to Northern Europe countries (PEREIRA et al., 2010) (Table 1).

TABLE $1 . \mathrm{NH}_{3}$ emission factors in naturally ventilated dairy cattle facilities.

\begin{tabular}{|c|c|c|}
\hline Emission Factor & Country & Author \\
\hline 20,0 g N-NH 3 normal-head ${ }^{-1}$ day $^{-1}$ & Sweden & NGWABIE et al., 2009 \\
\hline 23,5 g N-NH$_{3}$ normal-head ${ }^{-1}$ day $^{-1}$ & Switzerland & SCHRADE et al., 2012 \\
\hline 43,7 g N-NH 3 normal-head ${ }^{-1}$ day $^{-1}$ & Portugal & PEREIRA et al., 2010 \\
\hline
\end{tabular}

The most effective mitigation and simple to implement techniques include associated strategies (i) excreta pre-excretion, including diets with optimized crude protein content, leading to a decrease in the $\mathrm{N}$ excreted amount as urea present in urine (HRISTOV et al., 2011), and increased milk production at farm level (PEREIRA, 2010), (ii) and excreta post-excretion, mainly by exchanging conditions in terms of environmental control within the premises (temperature and air speed), use of floors that lead to reduced emissions, practice introduction or additive application in the produced excreta management (SOMMER et al., 2006; NDEGWA et al., 2008; PEREIRA et al., 2013). However, some outlined above actions are sometimes difficult to implement in existing facilities for cattle because they imply high costs, potential production losses and high time and hand labor consumption. An alternative to reduce $\mathrm{NH}_{3}$ emission is periodic additive applications on the floors/ parks and/ or effluent removal of tanks/ trenches. These additives are effective in reducing $\mathrm{NH}_{3}$ emissions, controlling the following processes: (i) $\mathrm{NH} 4+$ adsorption capacity during excreta decomposition, (ii) microorganism activity control through periodic additive applications being effective on excreta $\mathrm{pH}$ reduction, and (iii) urease enzyme activity inhibition.

\section{Facility design}

The best way to achieve a $\mathrm{NH}_{3}$ emission reduction in cattle facilities is the fast excreta removal (mainly urine) to storage structures or treatment systems. Studies employing models to the floors scale of naturally ventilated cattle facilities showed that a solid non-angled floor led to higher emissions than slatted floor as it favored the urease enzyme contact with urine urea (PEREIRA et al., 2011).

Slatted floor in cattle facilities promotes partial feces removal and urine drainage to a removal channel or storage tank located immediately under the slats, wherein $60 \%$ of $\mathrm{NH}_{3}$ volatilization 
originated from slatted and the $40 \%$ remainder from the channel or tank (OGINK \& KROODSMA, 1996). Compared to a slatted floor, the $3 \%$ inclination of a solid floor reduces $\mathrm{NH}_{3}$ volatilization in 21\%. Though, a solid floor with a double slope (V-shape) to a central drain (which promotes urine drainage) reduces in 50\% (BRAAM et al., 1997), as well as the perforation presence in a solid floor (less than $0.5 \%$ of total floor area) reduces $46 \% \mathrm{NH}_{3}$ volatilization (NDEGWA et al., 2008). Recently, HAMELIN et al. (2010) noted that in slatted floors, a border insertion on the upper beam surface (along the length) reduces $\mathrm{NH}_{3}$ emission from 23 to $42 \%$, because it decreases the contact surface area between urine and beam side faces, diverting urine directly to the channel under them. Furthermore, the combination of floor cleaning (scraping and/or washing) and urine drainage to a central drain reduces emission in 65\%, when compared to slatted floor (BRAAM et al., 1997, SOMMER et al., 2006). $\mathrm{NH}_{3}$ emission is decreased by about $50 \%$ in inclined solid floors, compared to slatted floor, and in addition, the top coat type applied to the floor surface does not significantly affect these emissions, because it has no effect on urease activity (SWIERSTRA et al., 1995). However, the flat top coat in angled floors can facilitate urine run-off, which may lead to smaller losses by $\mathrm{NH}_{3}$ volatilization.

Changing flooring type or urine-feces separating systems, aiming to reduce $\mathrm{NH}_{3}$ emissions, must be planned regarding to the farm profitability, because they have great costs, so it seems like a more viable solution to be adopted in new facility designs or rehabilitation of existing ones.

On the other hand, it has been shown, in several studies, that air speed and temperature decrease, or floor cooling, lead to significant $\mathrm{NH}_{3}$ emission reduction from the emitting surface (floors or tanks), due to these two factors having significant effect on $\mathrm{NH}_{3}$ convective mass transfer (RONG et al., 2009). Because cattle facilities are naturally ventilated particularly through openings for air renewal of large dimensions, such as it occurs in Portugal. It is very difficult to maintain a regular ventilation flow rate, which does not make practical the air speed control as a $\mathrm{NH}_{3}$ emission measure reduction (PEREIRA et al., 2010). Similarly, temperature control in naturally ventilated cattle facilities is quite difficult to achieve, because the temperature inside the premises depends on daily and seasonally outdoor fluctuations. However, positioning the air entrance openings, or placing curbs (1-1.5 m high) on floor level to prevent the direct hitting of the air flow and the floors (and/or tanks), can lead to $\mathrm{NH}_{3}$ emission reduction in about $52 \%$ of a solid $\mathrm{V}$-shaped floor (SWIERSTRA et al., 1995).

\section{Effluent management}

Studies conducted in dairy cattle facilities of Northwest Portugal (PEREIRA et al., 2010, 2011, 2012) suggest that, for temperature values between 5 and $25^{\circ} \mathrm{C}, \mathrm{NH}_{3}$ emissions are particularly important at times of the year when high temperatures occur (spring/summer), or in countries with temperate climates (average annual temperature between 15 and $25^{\circ} \mathrm{C}$ ). Particularly, PEREIRA et al. (2010) showed that $\mathrm{NH}_{3}$ emissions from uncovered areas of dairy cattle facilities accounted for between 69 and 92\% of housing system total $\mathrm{NH}_{3}$ emissions (indoor and outdoor areas). Consequently, these same studies suggest that additional mitigation measures should be introduced under these conditions compared to Northern Europe countries.

As ways of reducing $\mathrm{NH}_{3}$ emissions, it appears that frequent excreta scrape of non-inclined solid floor will have lower effect on $\mathrm{NH}_{3}$ volatilization because a thin film remains, which is a significant $\mathrm{NH}_{3}$ emission source (KROODSMA et al., 1993; BRAAM et al., 1997). The scraping followed by washing with pressurized water has been shown very effective to reduce $\mathrm{NH}_{3}$ emission (MISSELBROOK et al., 2006), but it has the disadvantage of leading to increased effluent volume, unless treated wastewater is reused (partially or fully) for facility washing. Nevertheless, the mix of floor type and cleaning frequency (washing and/or scraping) results in more effective $\mathrm{NH}_{3}$ emission reduction.

Another alternative to reduce emission is the periodic additive application on the floors/ parks (by spraying additive solutions over excreta) and/ or effluent removal trenches/tanks (by additive solutions). These additives are effective in reducing $\mathrm{NH}_{3}$ emissions, controlling the processes: 
(i) NH4+ adsorption capacity during excreta decomposition: clinoptilolite application (zeolite type clay mineral) has a potential for reducing $\mathrm{NH}_{3}$ emissions greater than $60 \%$ (NDEGWA et al., 2008).

(ii) microorganism activity control through periodic additive application effective on (1) reducing excreta $\mathrm{pH}$, in particular: (a) dilute sulfuric acid solution, lowering $\mathrm{pH}$ to 5.5, reducing $85 \% \mathrm{NH}_{3}$ volatilization (NDEGWA et al., 2008); (b) aluminum sulfate reducing $98 \% \mathrm{NH}_{3}$ emissions when applied to floors, and (c) diluted aluminum chloride solution allowing $52 \% \mathrm{NH}_{3}$ emission reduction, in addition mitigating odors and phosphorus solubilization (SMITH et al., 2004); or additives effective as (2) disinfectant, reducing microbial activity, as in formaldehyde diluted solution, which when applied to solid and slatted floors (tilted) has a potential to reduce $\mathrm{NH}_{3}$ emissions by $50 \%$ and $80 \%$, respectively (OGINK \& KROODSMA, 1996).

(iii) inhibition of the urease enzyme activity by periodically applying NBPT solution [N-(Nbutyl) thiophosphoric triamide] on the floor, has proven to be a very effective technique for reducing $\mathrm{NH}_{3}$ emission of outdoor parks (around 65\%) and dairy cattle facilities (by 40-50\%) (NDEGWA et al., 2008; MISSELBROOK et al., 2006; PEREIRA, 2010).

For effective $\mathrm{NH}_{3}$ emission reductions from dairy cattle facilities in Portugal we suggest that the implementation of any mitigation measures take place, firstly, in Spring and Summer and in the facility uncovered areas, because they have the largest emission sources. Nonetheless, this reduction must be cautiously made and integrated at farm level, as the emission reduction in one step (facilities, storage or land application) can increase emissions in remaining steps of effluent management or even losses due to nitrate ion leaching.

\section{CONCLUSIONS}

$\mathrm{NH}_{3}$ volatilization is the result of biochemical processes of excreta decomposition deposited on the floors of dairy cattle facilities and $\mathrm{NH}_{3}$ emission results from very complex physical processes commanded primarily by temperature, surface area, emission source exposure and air speed. Secreted compounds, transformation processes, and $\mathrm{NH}_{3}$ emission regulation mechanisms identification in facilities allows the control of $\mathrm{NH}_{3}$ losses. $\mathrm{NH}_{3}$ emissions in cattle facilities can be monitored using tracer gas, Ferm tubes and $\mathrm{CO}_{2}$ balance. The mitigation technique implementation, identified in this study, will contribute to animal livestock sustainability and applicable regulation compliance; however, there is limited number of studies published for warmer climate conditions than Northern Europe, such as Portugal, in which technical actions to reduce $\mathrm{NH}_{3}$ emissions should be evaluated.

\section{ACKNOWLEDGEMENTS}

This work was supported by European Union Funds (QREN/FEDER), under the project Ovislab ICT-2013-05-004-5314 ID-64757, and by national funds by FCT - Portuguese Foundation for Science and Technology, under the project PEst-OE/AGR/UI4033/2014 and project PTDC/AGR-PRO/119428/2010.

\section{REFERENCES}

BRAAM, C.R.; KETELAARS, J.J.M.H.; SMITS, M.C.J. Effects of floor design and floor cleaning on ammonia emission from cubicle houses for dairy cows. Netherlands Journal of Agricultural Science, Wageningen, v.45, n.1, p.49-64, 1997.

DORE, C.J.; JONES, B.M.R.; SCHOLTENS, R.; HUIS IN`T VELD, J.W.H.; BURGESS, L.R.; PHILLIPS, V.R. Measuring ammonia emission rates from livestock buildings and manure stores Part 2: Comparative demonstrations of three methods on the farm. Atmospheric Environment, Oxford, v.38, n.19, p.3017-3024, 2004.

FURTADO, D.A.; ROCHA, H.P.; AMANCIO, D.; NASCIMENTO, J.W.B.; GOMES, J.P.; SILVA, R.C. Thermal performance and concentration of gases in facilities for pigs in Semiarid Region from State of Paraiba-Brazil. Engenharia Agrícola, Jaboticabal, v.32, n.1, p.30-37, 2012. 
FURTADO, D.A.; ROCHA, H.P.; NASCIMENTO, J.W.B.; SILVA, J.H.V. Índices de conforto térmico e concentração de gases em galpões avícolas no semiárido Paraibano. Engenharia Agrícola, Jaboticabal, v.30, n.6, p.993-1002, 2010.

HAMELIN, L.; GODBOUT, S.; THÉRIAULT, R.; LEMAY, S.P. Evaluating ammonia emission potential from concrete slat designs for pig housing. Biosystems Engineering, San Diego, v.105, n.4, p.455-465, 2010.

HRISTOV, A.N.; HANIGAN, M.; COLE, A.; TODD, R.; MCALLISTER, T.A.; NDEGWA, P.M.; ROTZ, A. Review: Ammonia emissions from dairy farms and beef feedlots. Canadian Journal of Animal Science, Ontario, v.91, n.1, p.1-35, 2011.

KROODSMA, W.; HUIS IN'T VELD, J.W.H.; SCHOLTENS, R. Ammonia emission and its reduction from cubicle houses by flushing. Livestock Production Science, Amsterdam, v.35, n.3-4, p. 293-302, 1993.

MELSE, R.W.; OGINK, N.W.M.; RULKENS, W.H. Overview of European and Netherlands' regulations on airborne emissions from intensive livestock production with a focus on the application of air scrubbers. Biosystems Engineering, San Diego, v.104, n.3, p.289-298, 2009.

MISSELBROOK, T.H.; WEBB, J.; GILHESPY, S.L. Ammonia emissions from outdoor concrete yards used by livestock - quantification and mitigation. Atmospheric Environment, Oxford, v.40, n.35, p.6752-6763, 2006.

MOSQUERA, J.; MONTENY, G.J.; ERISMAN, J.W. Overview and assessment of techniques to measure emissions from animal houses: The case of the Netherlands. Environmental Pollution, Oxon, v.135, n.3, p.381-388, 2005.

NDEGWA, P.M.; HRISTOV, A.N.; AROGO, J.; SHEFFIELD, R.E. A review of ammonia emission mitigation techniques for concentrated animal feeding operations. Biosystems Engineering, San Diego, v.100, n.4, p.453-469, 2008.

NGWABIE, N.M.; JEPPSSON, K.-H.; NIMMERMARK, S.; SWENSSON, C.; GUSTAFSSON, G. Multi-location measurements of greenhouse gases and emission rates of methane and ammonia from a naturally-ventilated barn for dairy cows. Biosystems Engineering, San Diego, v.103, n.1, p.68-77, 2009.

NI, J.Q.; HEBER, A.J. Sampling and measurement of ammonia at animal facilities. Advances in Agronomy, San Diego, v.98, n.1, p.201-269, 2008.

OGINK, N.W.M.; KROODSMA, W. Reduction of ammonia emission from a cow cubicle house by flushing with water or a formalin solution. Journal of Agricultural Engineering Research, San Diego, v.63, n.3, p.197-204, 1996.

PEREIRA, J.L.S. Emissões de amoníaco e de gases com efeito de estufa erm instalações e gestão de efluentes de bovinicultura no NW de Portugal. 2010. 193 f. Tese (Doutorado em Engenharia Rural) - Universidade de Trás-os-Montes e Alto Douro, Vila Real, 2010.

PEREIRA, J.; BARNEZE, A.S.; MISSELBROOK, T.H.; COUTINHO, J.; MOREIRA, N.; TRINDADE, $\mathrm{H}$. Effects of a urease inhibitor and aluminium chloride alone or combined with a nitrification inhibitor on gaseous $\mathrm{N}$ emissions following soil application of cattle urine. Biosystems Engineering, San Diego, v.115, n.4, p.396-407, 2013.

PEREIRA, J.; FANGUEIRO, D.; MISSELBROOK, T.H.; CHADWICK, D.R.; COUTINHO, J.; TRINDADE, H. Ammonia and greenhouse gas emissions from slatted and solid floors in dairy cattle houses: A scale model study. Biosystems Engineering, San Diego, v.109, n.2, p.148-157, 2011. 
PEREIRA, J.; MISSELBROOK, T.H.; CHADWICK, D.R.; COUTINHO, J.; TRINDADE, H. Ammonia emissions from naturally ventilated dairy cattle buildings and outdoor concrete yards in Portugal. Atmospheric Environment, Oxford, v.44, n.28, p.3413-3421, 2010.

PEREIRA, J.; MISSELBROOK, T.H.; CHADWICK, D.R.; COUTINHO, J.; TRINDADE, H. Effects of temperature and dairy cattle excreta characteristics on potential ammonia and greenhouse gas emissions from housing: A laboratory study. Biosystems Engineering, San Diego, v.112, n.2, p.138-150, 2012.

RONG, L.; NIELSEN, P.V.; ZHANG, G. Effects of air flow and liquid temperature on ammonia emission surface: Experimental study on emission rate. Bioresource Technology, Oxon, v.100, n.20, p.4654-4661, 2009.

SAMER, M.; AMMON, C.; LOEBSIN, C.; FIEDLER, M.; BERG, W.; SANFTLEBEN, P.; BRUNSCH, R. Moisture balance and tracer gas technique for ventilation rates measurement and greenhouse gases and ammonia emissions quantification in naturally ventilated buildings. Building and Environment, Oxford, v.50, n.1, p.10-20, 2012.

SAMER, M.; LOEBSIN, C.; FIEDLER, M.; AMMON, C.; BERG, W.; SANFTLEBEN, P.; BRUNSCH, R. Heat balance and tracer gas technique for air flow rates measurement and gaseous emissions quantification in naturally ventilated livestock buildings. Energy and Buildings, Lausanne, v.43, n.12, p.3718-3728, 2011.

SCHRADE, S.; ZEYER, K.; GYGAX, L.; EMMENEGGER, L.; HARTUNG, E.; KECK, M. Ammonia emissions and emission factors of naturally ventilated dairy housing with solid floors and an outdoor exercise area in Switzerland. Atmospheric Environment, Oxford, v.47, n.1, p.183-194, 2012.

SMITH, D.R.; MOORE JR., P.A.; HAGGARD, B.E.; MAXWELL, C.V.; DANIEL, T.C.; VANDEVANDER, K.; DAVIS M.E. Effect of aluminium chloride and dietary phytase on relative ammonia losses from swine manure. Journal of Animal Science, Champaign, v.82, n.2, p.605-611, 2004.

SOMMER, S.G.; ZHANG, G.Q.; BANNINK, A.; CHADWICK, D.; MISSELBROOK, T.; HARRISON, R.; HUTCHINGS, N.J.; MENZI, H.; MONTENY, G.J.; NI, J.Q.; OENEMA, O.; WEBB, J. Algorithms determining ammonia emission from buildings housing cattle and pigs and from manure stores. Advances in Agronomy, San Diego, v.89, n.1, p.261-335, 2006.

SWIERSTRA, D.; SMITS, M.C.J.; KROODSMA, W. Ammonia emission from cubicle houses for cattle with slatted and solid floors. Journal of Agricultural Engineering Research, San Diego, v.62, n.2, p.127-132, 1995.

TEYE, F.K.; HAUTALA, M. Adaptation of an ammonia volatilization model for a naturally ventilated dairy building. Atmospheric Environment, Oxford, v.42, n.18, p.4345-4354, 2008.

TOLON, Y.A.; BARACHO, M.S.; NÄÄS, I.A.; ROJAS, M.; MOURA, D.J. Ambiências térmica, aérea e acústica para reprodutores suínos. Engenharia Agrícola, Jaboticabal, v.30, n.1, p.1-13, 2010. 